make plain something of which everyone who was privileged to know George Kelly was aware, that he was a scholar and thinker of the first magnitude.

When George first came to Johns Hopkins in 1980 he was concerned to limit his teaching and related commitments. He was anxious to preserve substantial time for research and writing and he wanted to spend most of each week in New York $\mathrm{Ci}$ ty. On a trial basis, he agreed to teach one seminar per semester and to spend a dayand-a-half in Baltimore each week during the fall and spring terms.

Formally, these remained his teaching arrangements throughout his eight years on the Hopkins faculty. Within a very short time, however, it was clear that a perfect match had been made. Colleagues and students in political theory, in the Humanities Center, and in several other humanities departments soon became aware of the extraordinary breadth of his learning, of the acuity and incisiveness of his mind, of the dedication and skill that characterized his quiet but remarkably effective teaching, and above all of the distinctively humane sensibility that was manifest in all of his thinking and each of his activities. His rigorous seminar on Hegel's Phenomenology quickly became a "must" for graduate students in several departments, he offered a wide range of independent reading courses and directed numerous theses and dissertations, and he became a regular participant in and major contributor to the colloquia, seminars, and other intellectual activities occurring on campus.

For his part, George found Hopkins to his liking. At lunch a few days before his tragic death, he said that the term just ending had been his most satisfying semester of teaching ever, and went on to say that his years here were the most rewarding of his academic career. Despite, or, as George himself would surely say, because of the steady expansion of his teaching and related university commitments, these were enormously fruitful years for him. He continued his many activities outside of the university, he was intensely active in the scholarly world, and he completed four major books and a long list of important articles and reviews. We are honored by our association with these splendid accomplishments. It has been a privilege and a joy to have him among us.

Kelly is survived by his wife Joanne Lyman of New York City; two sons, Charles Walton Kelly of Hollywood, California, and George Armstrong Kelly of Paris, France; a daughter, Eleanor Park Coughran of Canton, Massachusetts; a stepson, Christopher L. B. Finney, of Plymouth, Massachusetts, and a stepdaughter, Suzanne Finney-Sawits of Washington, D. C. It is requested that memorial gifts be made to the Sturgis Library. Barnstable, Massachusetts.

\author{
William E. Connolly \\ Richard E. Flathman \\ John G. A. Pocock \\ The Johns Hopkins \\ University, Baltimore
}

\section{John D. Lewis}

John D. Lewis, Emeritus Professor of Government at Oberlin College and a leading scholar and teacher in the field of political theory, died in Oberlin after a prolonged illness, on January 23, 1988.

Lewis was born in Paterson, New Jersey, on October 6, 1905. He earned a B.A. at Oberlin in 1928, followed by A.M. and $\mathrm{Ph} . \mathrm{D}$. degrees from the University of Wisconsin, in 1929 and 1934, respectively. He taught at Wisconsin from 1931 to 1935 before accepting the position at Oberlin, which he held until his retirement in 1972. He chaired the Department of Government during 19 of his 37 years at Oberlin. $\mathrm{He}$ also taught at Columbia University, the University of California at Berkeley, the University of Michigan, the University of Minnesota, and Wesleyan University. After his retirement he continued to teach at Case-Western Reserve University, Colorado College, and Penn State as well as at Oberlin. Lewis also held a Fulbright senior appointment at Oxford University in 1959-60.

A leader in the profession, Lewis served as book review editor of the APSR from 1952 to 1962, a member of the APSA national council from 1956 to 1958 , and APSA vice-president in 1962-63. He was 
also president of the Midwest Political Science Association in 1967-68.

Lewis specialized in European and American liberal-democratic theory. One of his first articles, in 1932, on representation, was co-authored by Charles A. Beard (whose isolationism he later distrusted). He subsequently published three books, including Against the Tyrant: The Tradition and Theory of Tyrannicide, with the late Oscar Jaszi, and Anti-Federalists Versus Federalists: Selected Documents, both of which we still widely read. He also published a work on the theory of Otto von Gierke. Lewis contributed articles to various journals, including APSR, The journal of Politics, and the International journal of Ethics, and wrote many book reviews. His approach to political theory was both textual and contextual; he had a keen eye for the historical contingencies informing political theories. He stood also for a principled politics free of ideological extremes of left and right. Of the American founders Jefferson particularly was his hero, for it was Jefferson who best exemplified for him the democratic faith, individual dignity, and the authority of persuasion in an age of cynicism and unprincipled power.

A master teacher, J. D. Lewis taught for decades a course in American political theory which became a model of its kind. He taught, as well, a full range of other courses in political theory and comparative politics. His teaching represented the highest standards of scholarly reading of texts informed by historical knowledge and a certain indefinable practical wisdom.
Under his influence Oberlin became one of the leading undergraduate educators of political scientists in the United States. Noted political scientists taught by Lewis over the years include Sheldon Wolin, Cecelia Kenyon, Kenneth Waltz, Tracy Strong, Jennifer Hochschild, Stephen Skowronek, and many others.

Lewis was a man of fierce integrity and great dignity, leavened by a dry, subtle, and delightful wit. He was utterly dedicated to academic life generally and to Oberlin in particular. He was both a wise and trusted advisor to Oberlin students and a most respected leader on the Oberlin faculty. As chair of the department for many years he was a superb administrator who used his talents to enhance the Oberlin Government Department to maintain its distinctive place in the discipline.

Surviving Lewis are his wife, Mary Jane Crow Lewis; two sons, David, of Princeton, and Donald, of Austin; and a daughter, Ellen, of Denver. His first wife, Ewart Kellogg Lewis, died in 1968. Memorial contributions may be sent to the John D. Lewis Memorial Fund for the Department of Government at Oberlin College. 